\title{
Non-cash Payment Transaction Projection Using ARIMAX : Efect of Calendar
}

\section{Proyeksi Transaksi Pembayaran Non-Tunai Menggunakan ARIMAX : Efek Kalender}

\author{
Muhammad Luthfi Setiarno Putera*
}

\begin{abstract}
As the most Moslem country, economic activity in Indonesia is often parallel with the movement of Qamariah (lunar) calendar which is different with Gregorian calendar. Using calender variation, this research attempts to look for modified time series model for non-cash payment projection (forecast) aim. The result shows that calendar variation plays statistically significant role on noncash payment, evidenced by significant payment in the month in which Eid Fitr occurs. The occurrence of Eid Fitr in the first and second week of the month is evidently characterized by increasing non-cash payment in one month earlier. The best model with highest accuracy for noncash payment projection is $\operatorname{ARIMAX}(2,1,1)$ as it is able to capture the pattern, trend and fluctuation. It also suggests the peak of non-cash payment will be in December.
\end{abstract}

Keywords: ARIMAX, Calendar Variation, Non-cash Payment.

\begin{abstract}
Abstrak
Sebagai negara berpenduduk Muslim terbesar di dunia, aktivitas perekonomian di Indonesia seringkali berhubungan dengan pergerakan hari pada kalender Qamariah (penanggalan Miladiyah). Menggunakan konfigurasi kalender, penelitian ini bertujuan untuk menemukan model deret waktu guna memproyeksi total transaksi pembayaran non-tunai yang semakin masif penggunaannya. Hasil penelitian menunjukkan bahwa variasi kalender memiliki pengaruh yang signifikan terhadap nilai transaksi, terbukti dari tingginya transaksi pada bulan jatuhnya Hari Raya Idul Fitri. Jika Hari Raya Idul Fitri jatuh pada minggu pertama dan minggu kedua, maka nilai transaksi pembayaran non-tunai justru lebih tinggi pada satu bulan sebelumnya. Model terbaik untuk proyeksi total transaksi pembayaran non-tunai adalah $\operatorname{ARIMAX}(2,1,1)$ karena mampu menangkap pola, tren dan dinamika fluktuasi. Diproyeksikan bahwa puncak nilai transaksi non-tunai pada 2019 jatuh pada bulan Desember.
\end{abstract}

Kata kunci: ARIMAX, Transaksi Pembayaran Non-tunai, Variasi Kalender.

\section{Pendahuluan}

Dalam beberapa tahun terakhir, teknologi kian berkembang pesat, yang ditandai dengan aksesibilitas Internet yang makin luas. Segala bentuk kegiatan ekonomi, termasuk transaksi pembayaran, dilakukan dengan kartu maupun gawai (gadget). Perubahan ini turut mendorong

* Fakultas Syariah, Institut Agama Islam Negeri Palangka Raya

Email:m.luthfi@iain-palangkaraya.ac.id 
lahirnya pola pembayaran dengan sistem non-tunai [1]. Suatu pembayaran dikategorikan sebagai non-tunai jika tidak melibatkan uang riil dalam aktivitas perekonomian. Atas pertimbangan efisiensi dan mobilitas nasabah, dikeluarkan media berupa Alat Pembayaran Menggunakan Kartu (APMK), yang terdiri atas kartu Debit, kartu ATM dan kartu kredit, oleh masing-masing bank. Selain itu, dikenal pula uang elektronik (e-money) yang saat ini menjadi opsi pembayaran yang diminati oleh generasi milenial karena mudah, aman, dan praktis sehingga tidak menutup kemungkinan jumlah peredaran uang tunai di masa depan akan semakin menurun [2].

Berdasarkan data Statistik Sistem Keuangan Indonesia, segmen penggunaan instrumen pembayaran non-tunai dapat dibagi ke dalam dua jenis dimana jenis pertama adalah transaksi dengan nominal minimal Rp 1.000.000 yang didominasi oleh kartu debet/ATM dan kartu kredit. Sementara, jenis kedua adalah nominal di bawah Rp 1.000.000 yang justru dikuasai oleh uang elektronik. Artinya, seluruh instrumen tersebut memiliki segmentasi dan pangsa pasar masingmasing, selaras dengan penelitian [3]. Dengan didukung regulasi yang tepat beserta infrastruktur yang mapan, kehadiran sistem pembayaran non-tunai dapat menjadi katalisator untuk mendorong roda perekonomian di masyarakat tetap bergerak positif [4].

Oleh karena itu, diperlukan identifikasi terhadap total transaksi pembayaran non-tunai melalui pemodelan deret waktu (time series). Hal ini untuk memudahkan peramalan (proyeksi) atas total pembayaran non-tunai sehingga pemerintah dapat merancang regulasi dan tindakan yang berkaitan dengan infrastruktur sistem keuangan, peredaran uang tunai dan sebagainya. Selain itu, dalam [5], hal ini dapat menjadi acuan bagi bank dan merchant yang mengeluarkan APMK dan UE dalam hal manajemen infrastruktur seperti penempatan mesin ATM, integrasi kartu pembayaran, dan perluasan akses UE.

Terdapat fenomena menarik dimana nilai transaksi non-tunai melonjak tajam menjelang hari besar keagamaan, terutama Hari Raya Idul Fitri. Dengan kata lain, konsumsi masyarakat di Indonesia mengalami puncaknya pada periode menjelang Hari Idul Fitri [6]. Fenomena tersebut mengindikasikan bahwa transaksi pembayaran non-tunai tidak terlepas dari pengaruh variasi kalender. Menurut Setiawan dkk. [7] mengemukakan bahwa model deret waktu yang mempertimbangkan efek dari variasi kalender akan menghasilkan ramalan yang lebih akurat. Anggraeni, Vinarti dan Kurniawati [8] juga mendapati bahwa pola konsumsi di negara dengan mayoritas penduduk beragama Islam seperti Indonesia terbukti dipengaruhi oleh dinamika kalender qamariyah.

Mengingat pentingnya peran sistem pembayaran non-tunai dalam menjaga stabilitas sistem keuangan, maka penelitian ini diangkat untuk melakukan identifikasi dan proyeksi terhadap total pembayaran non-tunai yang menggunakan APMK dan UE dengan konfigurasi variasi kalender. Dalam penelitian ini, beberapa model peramalan yang digunakan untuk proyeksi (forecasting) total pembayaran non-tunai via APMK dan UE, seperti regresi deret waktu, ARIMA dan ARIMAX, akan dibandingkan akurasinya.

\section{Model Deret Waktu}

\subsection{Variasi Kalender}

Variasi kalender merupakan kasus khusus dimana data cenderung mengikuti pola, dinamika atau pergerakan tertentu sesuai dengan penanggalan pada kalender, baik hari, minggu, bulan, kuartal, maupun semester. Berdasarkan Lin dkk [9], variasi kalender terbagi menjadi dua jenis, yaitu efek hari libur/hari perayaan dan efek hari kerja. Efek hari libur/perayaan seringkali memunculkan konfigurasi yang beragam karena adanya perbedaan karakteristik data. Di Indonesia, terdapat beberapa sistem penanggalan yang dapat digunakan untuk mengetahui efek kalender, antara lain kalender Qamariyah, yang menjadi patokan bagi pemerintah dalam 


\section{Muhammad Luthfi Setiarno Putera}

menetapkan Idul Fitri dan Idul Adha. Penggunaan beberapa kalender secara bersamaan tentu akan memunculkan efek terhadap analisis data secara bulanan [9]. Sebagai ilustrasi, persamaan (1) merepresentasikan model yang mempertimbangkan efek variasi kalender untuk bulan yang bertepatan dengan jatuhnya Idul Fitri, 1 bulan sebelumnya dan 1 bulan setelahnya, yaitu

$$
y_{t}=\beta_{1} D_{t}+\beta_{2} D_{t-1}+\beta_{3} D_{t+1}+\varepsilon_{t} .
$$

Variabel $D$ pada persamaan (1) adalah variabel indikator atau lazim dikenal dengan istilah dummy yang alternatif nilainya hanya ada dua, yaitu 0 dan 1 .

\subsection{Regresi Deret Waktu}

Regresi deret waktu adalah regresi berganda yang diterapkan untuk menganalisis hubungan antara variabel dependen $y_{t}, t=1,2, \ldots, n$ dan $k$ variabel independen $X_{1}, X_{2}, \ldots, X_{k}$ berdasarkan kaidah deret waktu $[10,11]$. Bentuk umum dari regresi deret waktu dengan variasi kalender yang memuat tren $t$ dan pola musiman dinyatakan pada persamaan (2), yaitu

$$
y_{t}=\beta_{0}+\beta_{1} M_{1, t}+\ldots \beta_{s} M_{s, t}+\delta t+\gamma_{1} L_{t}+\ldots \gamma_{m} L_{t-m}+\ldots+\gamma_{n} L_{t+n}+\varepsilon_{t},
$$

dengan

$$
\begin{array}{ll}
\beta_{1}, \beta_{2}, \ldots, \beta_{s} & : \text { parameter variabel dummy untuk musiman } \\
M_{1, t}, M_{2, t}, \ldots, M_{\mathrm{s}, t} & : \text { variabel dummy musiman } \\
\gamma_{1}, \gamma_{2}, \ldots, \gamma_{m}, \ldots, \gamma_{n} & : \text { parameter variabel dummy untuk efek kalender } \\
L_{t}, L_{t-m}, \ldots, L_{t+n} & : \text { variabel dummy efek kalender. }
\end{array}
$$

\subsection{Model ARIMA dan ARIMAX}

ARIMA (Autoregressive Integrated Moving Average) merupakan kombinasi dari model AR dengan orde $p$ dan MA dengan orde $q$ yang mengalami pembedaan (differencing) dengan orde $d$ untuk data deret waktu tidak berpola musiman [7]. Model ARIMA reguler dapat dinyatakan ke dalam persamaan (3),

$$
\phi_{p}(B)(1-B)^{d} y_{t}=\theta_{q}(B) \varepsilon_{t} \text {. }
$$

Pada beberapa kasus, data penjualan, konsumsi listrik, jumlah wisatawan, dan sebagainya, seringkali memiliki pola tertentu, yaitu meningkat atau menurun pada waktu-waktu tertentu [12]. Hal ini mengindikasikan bahwa data tersebut memiliki pola musiman. Model ARIMA untuk pola musiman adalah SARIMA (Seasonal ARIMA) atau ARIMA dengan musiman. Secara matematis, SARIMA dinotasikan ke dalam persamaan (4)

$$
\phi_{p}(B) \Phi_{P}\left(B^{S}\right)(1-B)^{d}\left(1-B^{S}\right)^{D} y_{t}=\theta_{q}(B) \Theta_{Q}\left(B^{S}\right) \varepsilon_{t},
$$

$$
\begin{aligned}
& \text { dengan } \\
& \phi_{p}(B)=1-\phi_{1} B-\phi_{2} B^{2}-\ldots-\phi_{p} B^{p} \\
& \Phi_{P}\left(B^{S}\right)=1-\Phi_{1} B^{S}-\Phi_{2} B^{2 S}-\ldots-\Phi_{P} B^{P S} \\
& \theta_{q}(B)=1-\theta_{1} B-\theta_{2} B^{2}-\ldots-\theta_{q} B^{q} \\
& \Theta_{Q}\left(B^{S}\right)=1-\Theta_{1} B^{S}-\Theta_{2} B^{2 S}-\ldots-\Theta_{Q} B^{Q S},
\end{aligned}
$$

dimana $S$ adalah periode musiman, $B$ adalah operator backshift, dan $\varepsilon_{t}$ adalah galat yang whitenoise dengan mean 0 dan varians konstan. Wei [13] mengusulkan teknik identifikasi melalui struktur otokorelasi pada plot ACF untuk mengetahui eksistensi pola musiman. 
Model ARIMAX (ARIMA with Exogenous) merupakan pengembangan ARIMA dengan keterlibatan variabel independen $($ kovariat $/ X)$ untuk memodelkan variabel $Y$ [11]. Penelitian ini menawarkan beberapa variabel dummy dan variabel kontinyu yang mewakili tren deterministik. Model pertama adalah ARIMAX dengan dummy efek variasi kalender, sementara model kedua adalah ARIMAX dengan dummy efek variasi kalender, dan tren deterministik yang diwakili oleh dummy musiman. Model ARIMAX pertama secara matematis adalah

$$
y_{t}=\beta_{0}+\sum_{i} \beta_{i} D_{t}+\sum_{i} \gamma_{i} D_{i, t}+\sum_{i} \varphi_{i} D_{i, t-1}+\frac{\theta_{q}(B) \Theta_{Q}\left(B^{S}\right)}{\phi_{p}(B) \Phi_{P}\left(B^{S}\right)(1-B)^{d}\left(1-B^{S}\right)^{D}} \varepsilon_{t} .
$$

Untuk model ARIMAX kedua, dapat direpresentasikan menjadi

$$
y_{t}=\delta_{1} t+\sum_{s} \beta_{s} M_{s, t}+\sum_{i} \gamma_{i} D_{i, t}+\sum_{i} \varphi_{i} D_{i, t-1}+\frac{\theta_{q}(B)}{\phi_{p}(B)(1-B)^{d}} \varepsilon_{t}
$$

dimana model kedua tidak lagi memiliki kemungkinan terpengaruh oleh efek musiman.

\section{Metode Analisis dan Data Penelitian}

Data yang digunakan dalam penelitian ini merupakan data sekunder yang dihimpun dari Bank Indonesia melalui laman https://www.bi.go.id/id/Default.aspx pada menu Statistik Sistem Pembayaran. Data yang menjadi fokus penelitian adalah data total transaksi pembayaran nontunai melalui APMK dan UE per bulan (Rp triliun) sebagai variabel dependen $\left(y_{t}\right)$ dimana $t$ menunjukkan waktu. Rentang data yang digunakan untuk analisis data dimulai dari Januari 2009 hingga Juni 2019. Jadi, total pengamatan pada penelitian ini adalah sebanyak 126 bulan.

Pada penelitian ini, juga dipertimbangkan variabel-variabel yang diduga mampu menjelaskan pola dan tren dari total transaksi pembayaran non-tunai yang dirinci sebagai berikut.

1. Variabel dummy untuk bulan Hari Idul Fitri

Variabel ini didesain untuk merepresentasikan posisi jatuhnya Hari Idul Fitri pada bulan ke- $t$ dalam kalender syamsiyyah (Masehi). Secara matematis, dinotasikan dalam

$D_{t-2}=\left\{\begin{array}{l}1, \text { bulan ke- }(t-2) \text { Idul Fitri ( } 2 \text { bulan sebelum Idul Fitri) } \\ 0, \text { bulan lainnya }\end{array}\right.$

$D_{t-1}=\left\{\begin{array}{l}1, \text { bulan ke- }(t-1) \text { Idul Fitri }(1 \text { bulan sebelum Idul Fitri }) \\ 0, \text { bulan lainnya }\end{array}\right.$

$D_{t}=\left\{\begin{array}{l}1, \text { bulan ke- } t \text { (bulan pada saat Idul Fitri) } \\ 0, \text { bulan lainnya }\end{array}\right.$

$D_{t+1}=\left\{\begin{array}{l}1, \text { bulan ke- }(t+1) \text { Idul Fitri (1 bulan setelah Idul Fitri) } \\ 0, \text { bulan lainnya }\end{array}\right.$

2. Variabel dummy untuk bulan dan minggu Hari Idul Fitri

Variabel ini dibuat mengacu pada karakteristik data penelitian Setiawan dkk [7] dan Ahmad dkk [10] dimana total permintaan dan transaksi mencapai puncaknya pada bulan ke- $t$ Idul Fitri jika 1 Syawal jatuh pada minggu ke-2, 3, dan 4 yang diduga serupa dengan karakteristik total pembayaran non-tunai. Untuk Idul Fitri yang jatuh pada minggu ke-1, maka kecenderungan puncak transaksi terjadi pada bulan sebelumnya. 


\section{Muhammad Luthfi Setiarno Putera}

$D_{i, t}=\left\{\begin{array}{l}1, \text { bulan ke- } t \text { (bulan pada saat Idul Fitri) pada minggu ke- } i \\ 0, \text { bulan lainnya }\end{array}\right.$

$D_{i, t-1}=\left\{\begin{array}{l}1, \text { bulan ke- }(t-1) \text { Idul Fitri pada minggu ke- } i \\ 0, \text { bulan lainnya }\end{array}\right.$

dengan $i=1,2,3,4$.

3. Variabel dummy bulanan

Variabel ini merepresentasikan bulan dalam 1 tahun kalender syamsiyyah (Masehi) dimana $M_{1}, M_{2}, \ldots, M_{12}$ untuk bulan Januari, Februari hingga Desember.

4. Variabel tren

Variabel ini dilibatkan dengan pertimbangan bahwa terdapat peningkatan total transaksi pembayaran non-tunai dari tahun ke tahun. Secara matematis, dinotasikan menjadi $t=1,2,3, \ldots, 126$.

Seluruh variabel dummy berperan sebagai variabel independen $(X)$. Introduksi variabel dummy agar mampu mengidentifikasi efek kalender pada total transaksi pembayaran melalui APMK dan UE dan menghasilkan proyeksi yang lebih akurat. Tabel 1 memberikan gambaran untuk hari Idul Fitri pada kalender Masehi beserta minggu kejadiannya.

Tabel 1. Periode Bulan, Minggu dan Tanggal Terjadinya Idul Fitri

\begin{tabular}{ccll}
\hline Waktu $(\boldsymbol{t})$ & Tahun & \multicolumn{1}{c}{ Tanggal } & Minggu terjadinya Idul Fitri \\
\hline $\mathbf{9}$ & 2009 & 20 September & Minggu ke-3 September \\
$\mathbf{2 1}$ & 2010 & 10 September & Minggu ke-2 September \\
$\mathbf{3 2}$ & 2011 & 31 Agustus & Minggu ke-4 Agustus \\
$\mathbf{4 4}$ & 2012 & 19 Agustus & Minggu ke-3 Agustus \\
$\mathbf{5 6}$ & 2013 & 8 Agustus & Minggu ke-2 Agustus \\
$\mathbf{6 7}$ & 2014 & 28 Juli & Minggu ke-4 Juli \\
$\mathbf{7 9}$ & 2015 & 17 Juli & Minggu ke-3 Juli \\
$\mathbf{9 1}$ & 2016 & 6 Juli & Minggu ke-1 Juli \\
$\mathbf{1 0 2}$ & 2017 & 25 Juni & Minggu ke-4 Juni \\
$\mathbf{1 1 4}$ & 2018 & 15 Juni & Minggu ke-2 Juni \\
$\mathbf{1 2 6}$ & 2019 & 5 Juni & Minggu ke-1 Juni \\
\hline
\end{tabular}

Sumber : Kementerian Agama RI (data diolah)

Pada penelitian ini, data dibagi menjadi dua, yaitu data training (in-sample) dan data testing (out-sample). Periode data training dimulai dari Januari 2009 hingga Desember 2017, sementara data testing dimulai dari Januari 2018 hingga Juni 2019. Data training digunakan untuk membentuk model, sementara data testing digunakan untuk mengetahui akurasi proyeksi (peramalan) dari alternatif model yang ditawarkan.

Kemudian, untuk model regresi deret waktu dan ARIMAX, dibentuk masing-masing dua alternatif model. Untuk model ARIMA, dipilih beberapa model sebagai alternatif untuk kemudian dibandingkan akurasinya. Seluruh model pada tahap ini menggunakan data training. Selanjutnya, melakukan pemilihan model terbaik berdasarkan indikator Root Mean Square Error (RMSE) dengan data testing sebagai acuan. Model dengan akurasi yang lebih baik umumnya memiliki RMSE yang lebih rendah. 


\section{Hasil dan Pembahasan}

Dalam penelitian ini, dibangun dua macam model dengan konfigurasi berikut.

1) Model 1

Model ini dibangun dengan mengeliminasi efek variasi kalender terhadap total transaksi pembayaran non-tunai dengan menggunakan persamaan (7)

$$
Y_{t}=\beta_{0}+\beta_{1} D_{t-2}+\beta_{2} D_{t-1}+\beta_{3} D_{t}+\beta_{4} D_{t+1}+\sum_{i=1}^{4} \gamma_{i} D_{i, t}+\sum_{i=1}^{4} \varphi_{i} D_{i, t-1}+W_{t}
$$

hingga menyisakan tren stokastik dan musiman yang diwakili oleh galat $W_{t}$.

2) Model 2

Model ini dibangun dengan kombinasi dari model 1 (tanpa konstanta $\beta_{0}$ ) dan tren deterministik serta musiman (bulan kalender Masehi) dan diperoleh persamaan (8)

$$
Y_{t}=\beta_{1} t+\delta_{0} D_{t-2}+\delta_{1} D_{t-1}+\delta_{2} D_{t}+\delta_{3} D_{t+1}+\sum_{i=1}^{4} \gamma_{i} D_{i, t}+\sum_{i=1}^{4} \varphi_{i} D_{i, t-1}+\sum_{j=1}^{12} \lambda_{j} M_{j}+W_{t}
$$

yang menyisakan galat $W_{t}$ yang mewakili nilai dari variabel yang tidak dilibatkan dalam model.

Persamaan (7) dan (8) dimodelkan dengan regresi deret waktu dan ARIMAX. Sementara, model ARIMA dibangun hanya berdasarkan nilai transaksi pembayaran non-tunai secara temporal.

\subsection{Model Regresi Deret Waktu}

Persamaan (7) dan (8) merupakan representasi dari regresi deret waktu dengan pertimbangan galat $W_{t}$ dari masing-masing persamaan tidak dimodelkan kembali dengan menggunakan ARIMA. Berikut ini merupakan model regresi deret waktu untuk transaksi pembayaran non-tunai pada data training dengan parameter yang sudah diestimasi.

1) Model 1

$$
\begin{aligned}
\hat{Y}_{t}= & 332,6+2 D_{t-2}+69,3 D_{t-1}+86,4 D_{t}+6,5 D_{t+1}+51 D_{1, t}-170 D_{2, t}-117 D_{3, t}+ \\
& 145 D_{1, t-1}-112 D_{2, t-1}-102 D_{3, t-1}
\end{aligned}
$$

Variabel dummy $D_{4, t}$ dan $D_{4, t-1}$ dikeluarkan dari model untuk menghindari multikolinearitas. Dengan $\alpha$ sebesar 5\%, hampir semua parameter tidak signifikan kecuali konstanta. Namun, pada pemodelan deret waktu, hal ini tidak dapat dijadikan acuan utama dan satu-satunya untuk melihat kebaikan model.

2) Model 2

$$
\begin{aligned}
\hat{Y}_{t}= & 4,15 t-2,17 D_{t-2}+12,3 D_{t-1}+26,8 D_{t}-2,97 D_{t+1}-54,7 D_{1, t}-41,6 D_{2, t}-16,5 D_{3, t}+ \\
& 49,1 D_{1, t-1}+7,1 D_{2, t-1}-4,7 D_{3, t-1}+111,07 M_{1}+83,98 M_{2}+116,23 M_{3}+104,61 M_{4}+ \\
& 115,09 M_{5}+112,33 M_{6}+120,81 M_{7}+110,1 M_{8}+97,98 M_{9}+109,64 M_{10}+98,92 M_{11}+ \\
& 131,42 M_{12}
\end{aligned}
$$

Pada model 2, $D_{4, t}$ dan $D_{4, t-1}$ dikeluarkan dari model untuk menghindari multikolinieritas. Dengan $\alpha$ sebesar 5\%, dummy yang signifikan adalah $D_{t}, D_{1, t}, D_{2, t}$, $D_{1, t-1}$, dan seluruh dummy bulanan sebanyak 12 parameter. Selain itu, tren juga memiliki pengaruh yang signifikan pada transaksi pembayaran non-tunai. Dengan demikian, nilai pembayaran non-tunai terbukti secara statistik meningkat dari tahun ke tahun. Meski tidak semua parameter signifikan, namun seluruh parameter tetap dimasukkan dalam model. Hal terpenting adalah akurasi peramalan yang dihasilkan [14]. 
Dari koefisien parameter $D_{t}$ sebesar 26,8, terjadinya Idul Fitri memiliki pengaruh yang positif terhadap total transaksi pembayaran tepat pada bulan jatuhnya Idul Fitri. Sedangkan, $D_{1, t}$ dan $D_{2, t}$ yang bernilai negatif menandakan transaksi pembayaran non-tunai di bulan dimana Idul Fitri jatuh pada minggu ke-1 dan ke-2 menurun secara signifikan dibandingkan bulan sebelumnya. Selain itu, bulan Desember (akhir tahun) terbukti menjadi bulan dengan capaian transaksi pembayaran tertinggi. Selanjutnya, dua model ini digunakan untuk memproyeksikan transaksi pembayaran non-tunai untuk data testing.

\subsection{Model ARIMA}

Model ARIMA dibangun hanya berdasarkan atas nilai pembayaran non-tunai beserta nilainya pada periode-periode sebelumnya. Berdasarkan uji ADF, total pembayaran non-tunai terbukti tidak stasioner dalam mean. Untuk data tidak stasioner dalam mean, perlu dilakukan pembedaan (differencing) agar data menjadi stasioner. Pembedaan dilakukan secara reguler, yaitu orde $d$ sebesar 1. Gambar 1 adalah plot ACF dan PACF dari total pembayaran non-tunai yang sudah mengalami pembedaan reguler $d=1$.

Berdasarkan Gambar 1, ACF menunjukkan nilai yang signifikan pada lag-1, 4 dan 13. PACF menunjukkan nilai yang signifikan pada lag-1, 2, 4, 5, 11, 12 dan 13. ACF dan PACF ARIMA reguler menawarkan beberapa opsi berbeda, seperti MA(1), MA(2) atau $\operatorname{ARMA}(1,1)$ karena polanya mirip dengan kriteria orde dalam Box, Jenkins dan Reinsel [15].
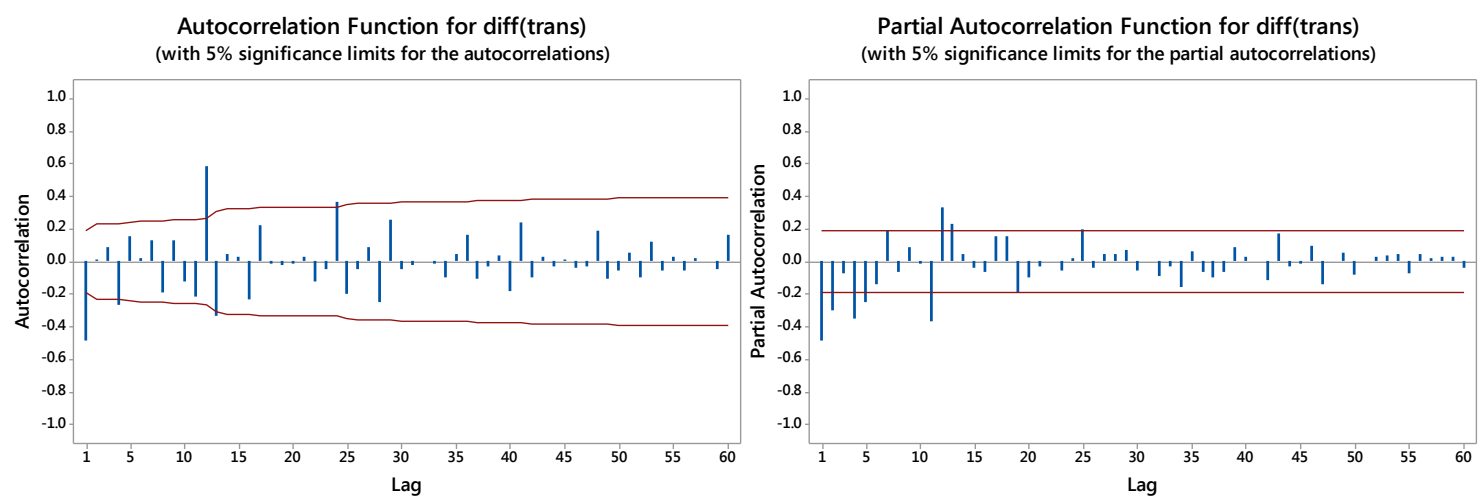

Gambar 1. ACF dan PACF Hasil Pembedaan (Differencing)

Gambar 1 juga mengindikasikan bahwa terdapat pola musiman untuk total pembayaran non-tunai. Hal ini terlihat dari ACF pada lag musiman yang signifikan, terutama pada lag ke-12 dan 24. ACF lag musiman juga menunjukkan nilai yang menurun secara eksponensial. PACF pada lag musiman hanya signifikan pada lag ke-12, sementara PACF lag ke-24, 36, dan seterusnya nilainya mendekati 0 . Mengacu pada Box, Jenkins dan Reinsel [15], orde musiman yang berlaku untuk data ini hanya 1 kemungkinan, yaitu $(1,0,0)^{12}$.

Jadi, terdapat 3 opsi model ARIMA, yaitu ARIMA $(0,1,1)(1,0,0)^{12}, \operatorname{ARIMA}(0,1,2)(1,0,0)^{12}$, dan ARIMA $(1,1,1)(1,0,0)^{12}$. Tabel 2 menyajikan signifikansi parameter dan Akaike Information Criterion (AIC) dari tiap model menggunakan data training.

Tabel 2. Signifikansi Parameter ARIMA dengan Musiman

\begin{tabular}{|c|l|c|c|c|}
\hline Model & Parameter & Koefisien & $\boldsymbol{p}$-value & AIC \\
\hline \multirow{2}{*}{ ARIMA $(0,1,1)(1,0,0)^{12}$} & $\mathrm{MA}(1)$ & 0,731 & $<0,0001$ & \multirow{2}{*}{885,046} \\
\cline { 2 - 5 } & $\mathrm{AR}(1) \_12$ & 0,916 & $<0,0001$ & \\
\hline
\end{tabular}




\begin{tabular}{|l|l|c|c|c|}
\hline \multirow{4}{*}{$\operatorname{ARIMA}(0,1,2)(1,0,0)^{12}$} & $\mathrm{MA}(1)$ & 0,942 & $<0,0001$ & \multirow{3}{*}{879,627} \\
\cline { 2 - 4 } & $\mathrm{MA}(2)$ & $-0,263$ & 0,0075 & \\
\cline { 2 - 4 } & $\mathrm{AR}(1) \_12$ & 0,937 & $<0,0001$ & \\
\hline \multirow{3}{*}{ ARIMA(1,1,1)(1,0,0) } & AR(1) & $-0,300$ & 0,016 & \multirow{2}{*}{880,774} \\
\cline { 2 - 4 } & $\mathrm{MA}(1)$ & 0,616 & $<0,0001$ & \\
\cline { 2 - 4 } & AR(1)_12 & 0,932 & $<0,0001$ & \\
\hline
\end{tabular}

Tabel 2 menunjukkan bahwa seluruh parameter pada tiga alternatif model ARIMA signifikan pada $\alpha=5 \%$. Artinya, transaksi pembayaran non-tunai terbukti secara statistik dipengaruhi pula oleh transaksi pada periode sebelumnya serta variabel yang tidak dilibatkan dalam model (galat) pada periode sebelumnya. Model yang terbukti lebih sederhana dan tepat berdasarkan AIC adalah ARIMA $(0,1,2)(1,0,0)^{12}$. Persamaan $(11)$ adalah $\operatorname{ARIMA}(0,1,2)(1,0,0)^{12}$ berdasarkan data training untuk transaksi pembayaran non-tunai pada waktu ke-t.

$$
Y_{t}=Y_{t-1}+0,937 Y_{t-12}-0,937 Y_{t-13}+\varepsilon_{t}+0,942 \varepsilon_{t-1}-0,263 \varepsilon_{t-2}
$$

\subsection{Model ARIMAX}

Sebelum memulai konstruksi model ARIMAX untuk data training, pola ACF dan PACF dari galat model regresi deret waktu, yaitu model 1 dan model 2, dianalisis terlebih dulu.

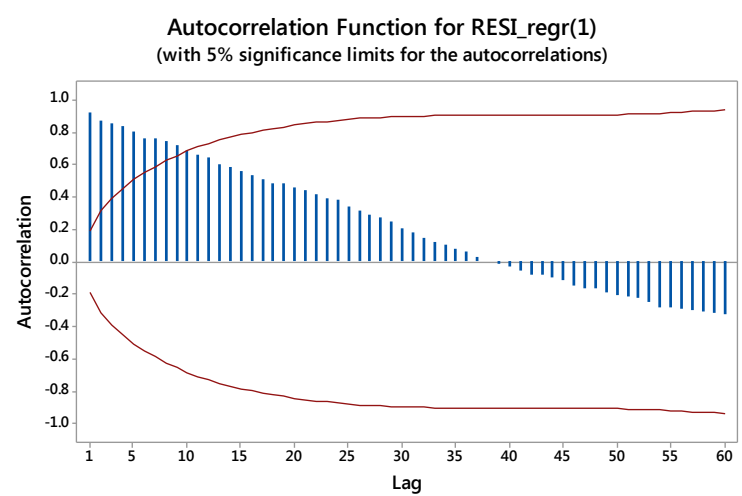

Model 1

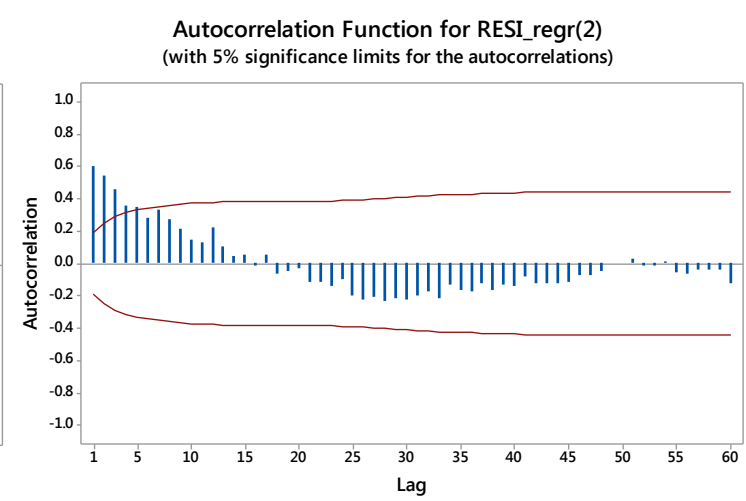

Model 2

Gambar 2. Plot ACF Galat Model Regresi Deret Waktu

Gambar 2 mengindikasikan bahwa galat dua model tidak stasioner sehingga perlu dilakukan operasi pembedaan (difference) secara reguler. Setelah di-difference, Gambar 3 menampilkan ACF dan PACF hasil pembedaan galat model regresi deret waktu 1 dan 2.

(a) Model 1 

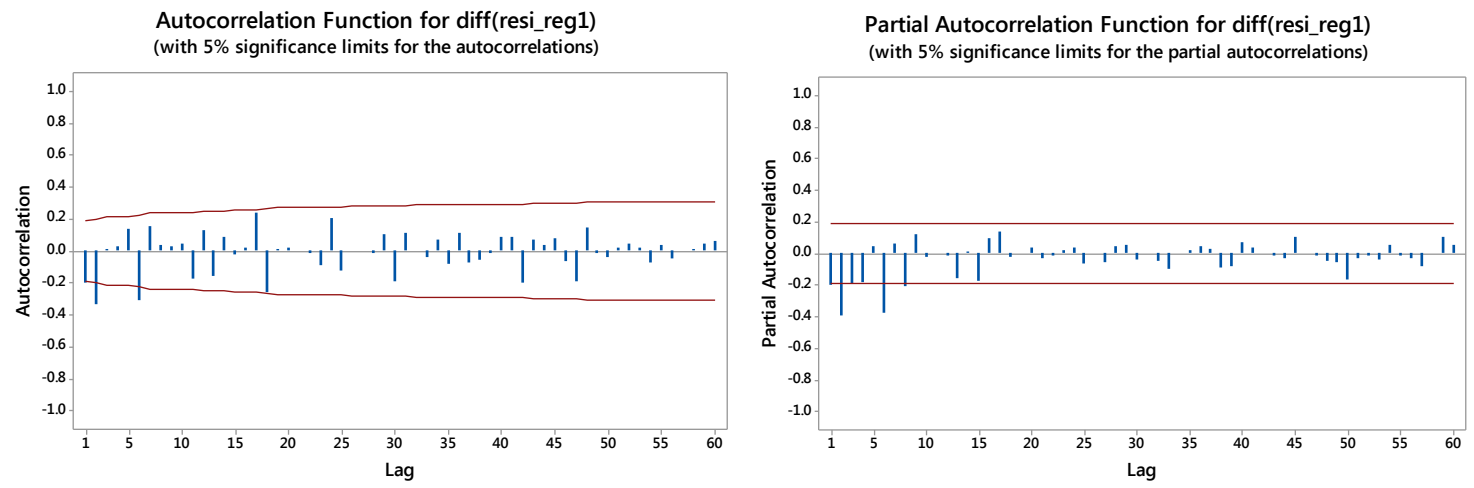

(b) Model 2
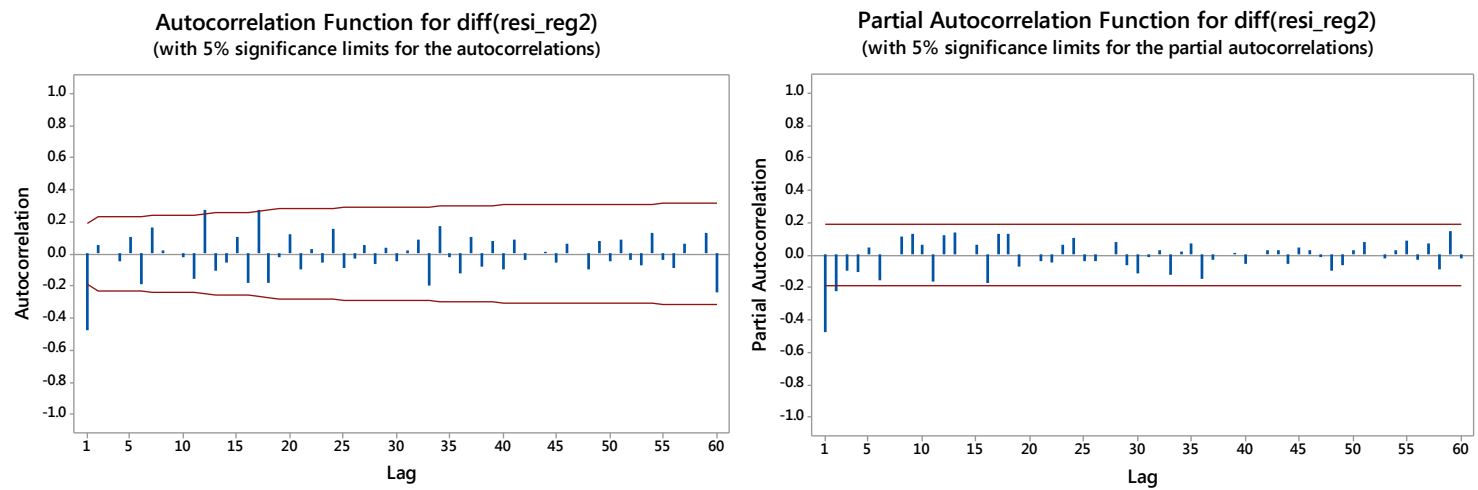

Gambar 3. ACF dan PACF Galat Hasil Pembedaan Model Regresi Deret Waktu

Untuk menghasilkan ramalan dari model ARIMAX, maka galat pada persamaan (9) dan (10) dimodelkan terlebih dulu dengan ARIMA, lalu ditambahkan dengan estimasi dari model regresi deret waktu. Tabel 3 menyajikan opsi model ARIMAX beserta ringkasan RMSE dari data training untuk seluruh alternatif model ARIMAX.

Tabel 3. RMSE Model ARIMAX Data Training

\begin{tabular}{|c|l|c|l|c|}
\hline Model & \multicolumn{1}{|c|}{ Alternatif } & RMSE & Alternatif & RMSE \\
\hline \multirow{3}{*}{ Model 1 } & $\operatorname{ARIMAX}(0,1,1)$ & 36,01 & $\operatorname{ARIMAX}(2,1,0)$ & 34,90 \\
\cline { 2 - 5 } & $\operatorname{ARIMAX}(0,1,2)$ & 34,47 & $\operatorname{ARIMAX}(2,1,1)$ & 34,77 \\
\hline \multirow{3}{*}{ Model 2 } & $\operatorname{ARIMAX}(0,1,1)$ & 11,03 & $\operatorname{ARIMAX}(2,1,1)$ & 11,21 \\
\cline { 2 - 5 } & $\operatorname{ARIMAX}(1,1,0)$ & 11,43 & $\operatorname{ARIMAX}(1,1,2)$ & $10,99 *$ \\
\cline { 2 - 6 } & $\operatorname{ARIMAX}(2,1,0)$ & 11,13 & \multicolumn{2}{|c}{} \\
\cline { 2 - 6 } & &
\end{tabular}

Ket. * model dengan RMSE terendah

Berdasarkan Tabel 3, ARIMAX $(0,1,2)$ adalah model training dengan akurasi terbaik untuk model 1, sementara ARIMAX $(1,1,2)$ merupakan model training yang terbaik untuk model 2. Berikut ini persamaan ARIMAX dengan akurasi terbaik dari masing-masing model training.

- Model 1 


$$
\begin{aligned}
\hat{Y}_{t}= & 332,6+2 D_{t-2}+69,3 D_{t-1}+86,4 D_{t}+6,5 D_{t+1}+51 D_{1, t}-170 D_{2, t}-117 D_{3, t}+ \\
& 145 D_{1, t-1}-112 D_{2, t-1}-102 D_{3, t-1}+\frac{1-0,265 B-0,331 B^{2}}{1-B} \varepsilon_{t}
\end{aligned}
$$

- Model 2

$$
\begin{aligned}
\hat{Y}_{t}= & 4,15 t-2,17 D_{t-2}+12,3 D_{t-1}+26,8 D_{t}-2,97 D_{t+1}-54,7 D_{1, t}-41,6 D_{2, t}- \\
& 16,5 D_{3, t}+49,1 D_{1, t-1}+7,1 D_{2, t-1}-4,7 D_{3, t-1}+111,07 M_{1}+83,98 M_{2}+ \\
& 116,23 M_{3}+104,61 M_{4}+115,09 M_{5}+112,33 M_{6}+120,81 M_{7}+110,1 M_{8}+ \\
& 97,98 M_{9}+109,64 M_{10}+98,92 M_{11}+131,42 M_{12}+\frac{1-0,643 B+0,063 B^{2}}{(1-0,996 B)(1-B)} \varepsilon_{t}
\end{aligned}
$$

\subsection{Diagnostic Checking}

Pemeriksaan asumsi (diagnostic checking) merupakan tahapan untuk mengetahui

\begin{tabular}{|c|c|c|c|c|}
\hline \multicolumn{2}{|c|}{ Alternatif model } & $\begin{array}{c}\text { Asumsi white } \\
\text { noise }\end{array}$ & $\begin{array}{c}\text { Asumsi } \\
\text { independen }\end{array}$ & $\begin{array}{c}\text { Asumsi } \\
\text { normalitas }\end{array}$ \\
\hline \multirow{2}{*}{$\begin{array}{l}\text { Regresi } \\
\text { deret waktu }\end{array}$} & Model 1 & Tidak memenuhi & Tidak memenuhi & Tidak memenuhi \\
\hline & Model 2 & Tidak memenuhi & Tidak memenuhi & Tidak memenuhi \\
\hline \multirow{3}{*}{$\begin{array}{l}\text { ARIMA } \\
\text { musiman }\end{array}$} & $\operatorname{ARIMA}(0,1,1)(1,0,0)^{12}$ & Memenuhi & Memenuhi & Memenuhi \\
\hline & $\operatorname{ARIMA}(0,1,2)(1,0,0)^{12}$ & Memenuhi & Memenuhi & Memenuhi \\
\hline & $\operatorname{ARIMA}(1,1,1)(1,0,0)^{12}$ & Memenuhi & Memenuhi & Memenuhi \\
\hline \multirow{4}{*}{$\begin{array}{l}\text { ARIMAX } \\
\text { Model } 1\end{array}$} & $\operatorname{ARIMAX}(0,1,1)$ & Tidak memenuhi & Memenuhi & Memenuhi \\
\hline & $\operatorname{ARIMAX}(0,1,2)$ & Tidak memenuhi & Memenuhi & Memenuhi \\
\hline & $\operatorname{ARIMAX}(2,1,0)$ & Tidak memenuhi & Memenuhi & Memenuhi \\
\hline & $\operatorname{ARIMAX}(2,1,1)$ & Tidak memenuhi & Memenuhi & Tidak memenuhi \\
\hline \multirow{5}{*}{$\begin{array}{l}\text { ARIMAX } \\
\text { Model } 2\end{array}$} & $\operatorname{ARIMAX}(0,1,1)$ & Memenuhi & Memenuhi & Memenuhi \\
\hline & $\operatorname{ARIMAX}(1,1,0)$ & Memenuhi & Memenuhi & Memenuhi \\
\hline & $\operatorname{ARIMAX}(2,1,0)$ & Memenuhi & Memenuhi & Tidak memenuhi \\
\hline & $\operatorname{ARIMAX}(2,1,1)$ & Memenuhi & Memenuhi & Memenuhi \\
\hline & ARIMAX $(1,1,2)$ & Memenuhi & Memenuhi & Memenuhi \\
\hline
\end{tabular}
terpenuhinya asumsi yang disyaratkan atas galat model deret waktu. Uji independen dilakukan dengan memeriksa plot ACF dan PACF dari tiap galat model dan uji white noise dilakukan dengan uji Ljung-Box. Lalu, uji normalitas dilakukan dengan uji Kolmogorov-Smirnov. Tabel 4 menyajikan ringkasan dari hasil pengujian tersebut untuk seluruh alternatif model pada $\alpha=5 \%$.

Tabel 4. Hasil Pemenuhan Asumsi Galat Model Deret Waktu

Tabel 4 menunjukkan bahwa regresi deret waktu tidak memenuhi asumsi yang disyaratkan. ARIMA dan ARIMAX model 2 memberikan hasil yang memenuhi kriteria statistik pemodelan, meskipun penilaian kebaikan model tidak hanya dilihat dari pemenuhan asumsi saja.

\subsection{Proyeksi Pembayaran Non-Tunai dan Pemilihan Model Terbaik}




\section{Muhammad Luthfi Setiarno Putera}

Kriteria pemilihan model proyeksi terbaik didasarkan dari model dengan RMSE testing (out-sample) terendah.

Tabel 5. Ukuran RMSE Model Training dan Testing

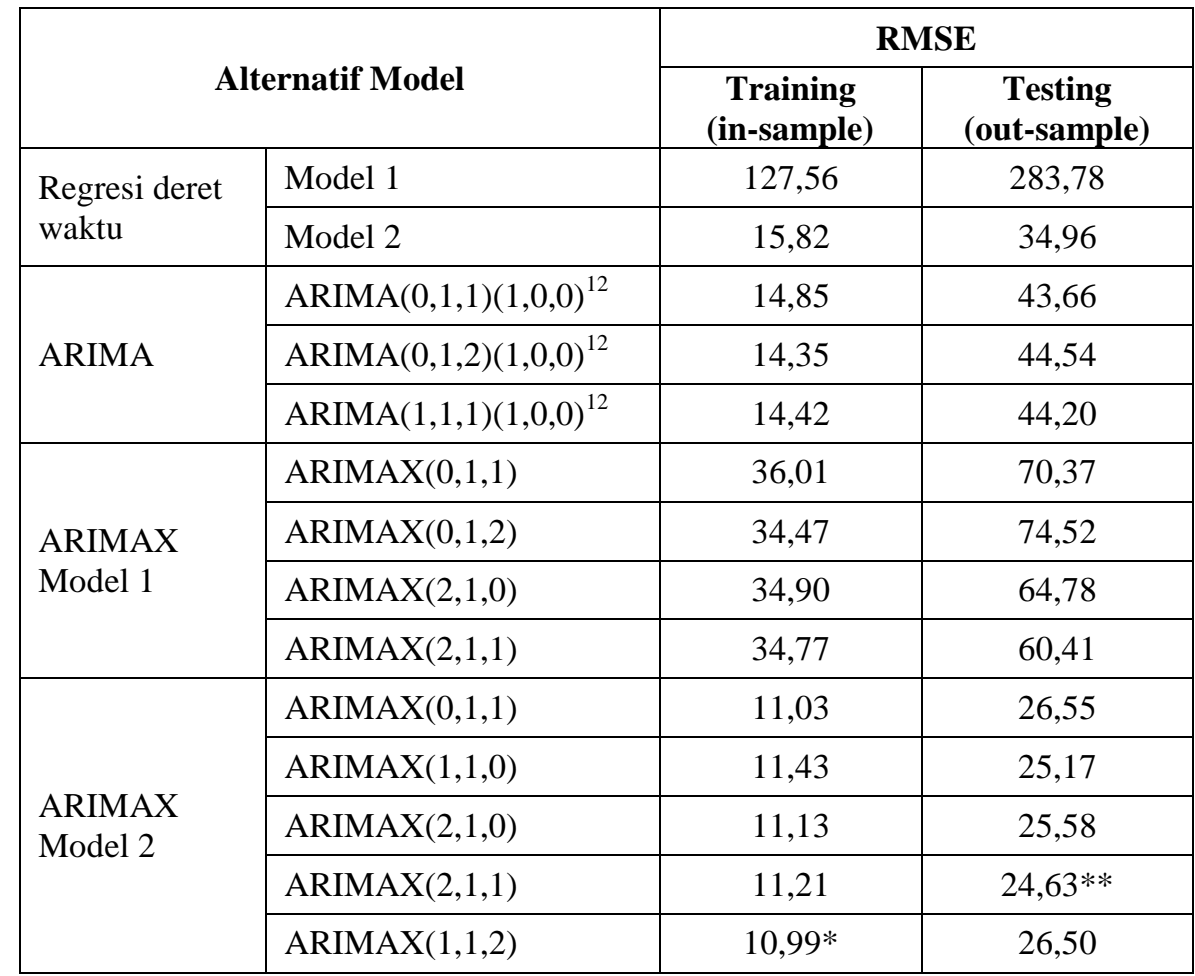

Tabel 5 mengindikasikan bahwa ARIMAX Model 2 adalah model dengan akurasi terbaik. Selain itu, regresi deret waktu model 2 di luar dugaan mampu memberikan akurasi proyeksi yang justru lebih baik daripada ARIMA, meskipun galat modelnya melanggar asumsi. Berdasarkan hasil ini, dapat dikatakan bahwa pelibatan konfigurasi variasi kalender ke dalam model ARIMAX mampu menghasilkan proyeksi total pembayaran non-tunai yang lebih akurat.

Secara umum, Gambar 4 menyajikan tiap model terbaik dari tiga model deret waktu yang digunakan pada penelitian ini. Meski mampu mengikuti pola total pembayaran non-tunai, regresi deret waktu model 2 cenderung konsisten menghasilkan proyeksi yang under-estimate (di bawah nilai aktual). Sementara, model lainnya $\operatorname{ARIMA}(0,1,1)(1,0,0)^{12}$ juga mampu mengikuti pola data, meski kelemahannya terlihat pada ketidakmampuan dalam memproyeksikan pembayaran nontunai pada bulan jatuhnya Idul Fitri. Hal ini disebabkan tidak adanya variabel dummy yang mewakili efek kalender dalam model. 


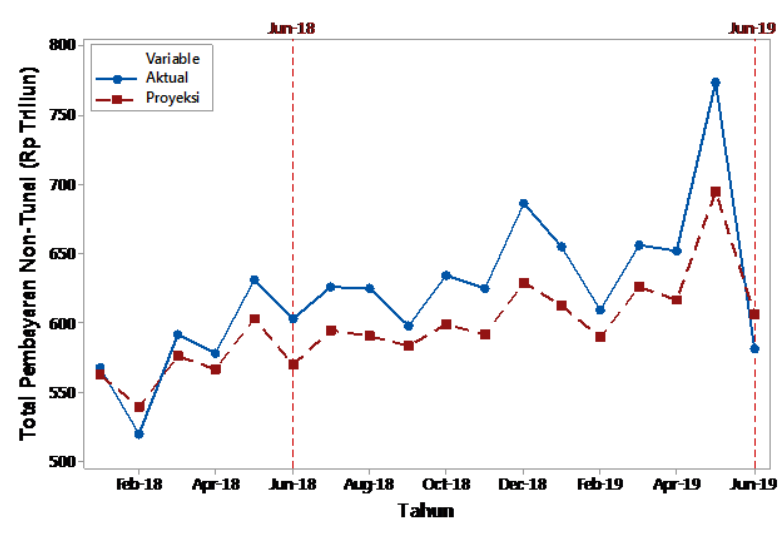

(a) Regresi Deret Waktu Model 2

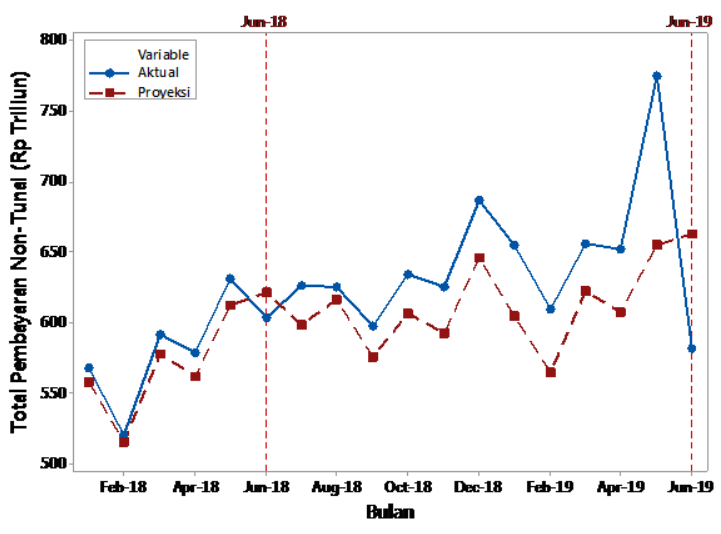

(b) $\operatorname{ARIMA}(0,1,1)(1,0,0)^{12}$

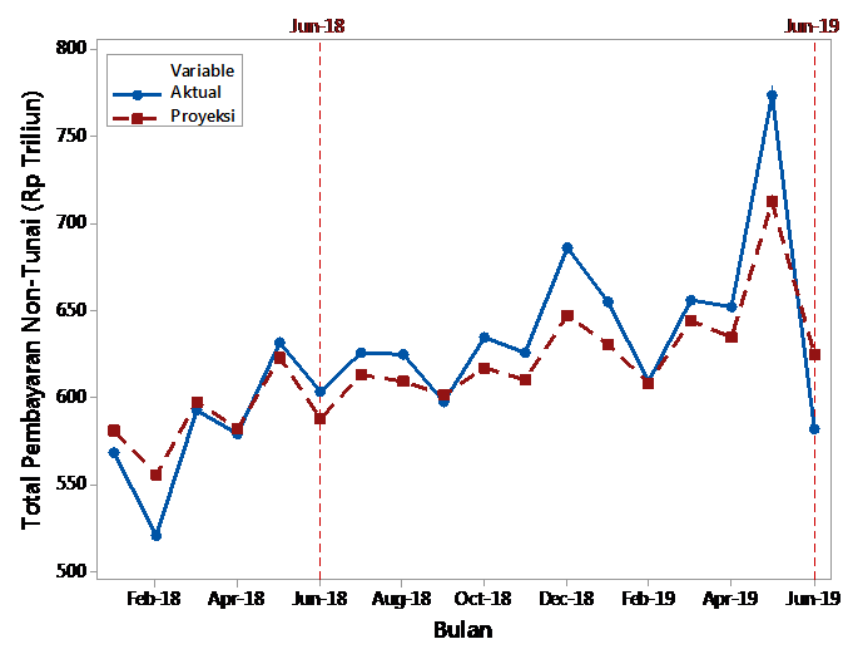

(c) ARIMAX $(2,1,1)$ Model 2

Ket. garis tegak lurus merah! adalah bulan terjadinya Idul Fitri

Gambar 4. Plot Deret Waktu Proyeksi Data Testing (Out-sample)

Gambar 4(c) menunjukkan bahwa model ARIMAX $(2,1,1)$ terbukti lebih baik dari model regresi deret waktu dan ARIMA karena tidak pernah keliru dalam menentukan arah kenaikan atau penurunan data. Bahkan, pada bulan tertentu, selisih antara nilai aktual dan nilai proyeksi hampir bernilai 0 (proyeksi akurat). Model $\operatorname{ARIMAX}(2,1,1)$ juga mampu untuk menduga puncak dari total pembayaran non-tunai yang menjelang atau bertepatan dengan bulan terjadinya Idul Fitri maupun akhir tahun. Berikut ini persamaan $\operatorname{ARIMAX}(2,1,1)$ sebagai model terbaik dalam memproyeksikan (meramalkan) total pembayaran non-tunai, terutama untuk data testing.

$$
\begin{aligned}
\hat{Y}_{t}= & 4,15 t-2,17 D_{t-2}+12,3 D_{t-1}+26,8 D_{t}-2,97 D_{t+1}-54,7 D_{1, t}-41,6 D_{2, t}-16,5 D_{3, t}+ \\
& 49,1 D_{1, t-1}+7,1 D_{2, t-1}-4,7 D_{3, t-1}+111,07 M_{1}+83,98 M_{2}+116,23 M_{3}+104,61 M_{4}+ \\
& 115,09 M_{5}+112,33 M_{6}+120,81 M_{7}+110,1 M_{8}+97,98 M_{9}+109,64 M_{10}+98,92 M_{11}+ \\
& 131,42 M_{12}+\frac{1+0,681 B}{\left(1+1,215 B+0,476 B^{2}\right)(1-B)} \varepsilon_{t}
\end{aligned}
$$


Hasil pemeriksaan asumsi dari galat model $\operatorname{ARIMAX}(2,1,1)$ diperoleh bahwa asumsi white noise, asumsi independen dan asumsi normalitas seluruhnya terpenuhi. Jadi, dapat dikatakan bahwa model ARIMAX $(2,1,1)$ telah memenuhi kriteria yang disyaratkan untuk menjadi model terbaik, yaitu memiliki RMSE testing (out-sample) terendah dan memenuhi asumsi galat. Hasil ini semakin memperkuat bukti bahwa persamaan (12) adalah model terbaik untuk memproyeksikan nilai dari total pembayaran non-tunai dengan APMK dan UE. Gambar 5 berikut turut mencakup proyeksi pembayaran non-tunai untuk Juli 2019 - Desember 2019.

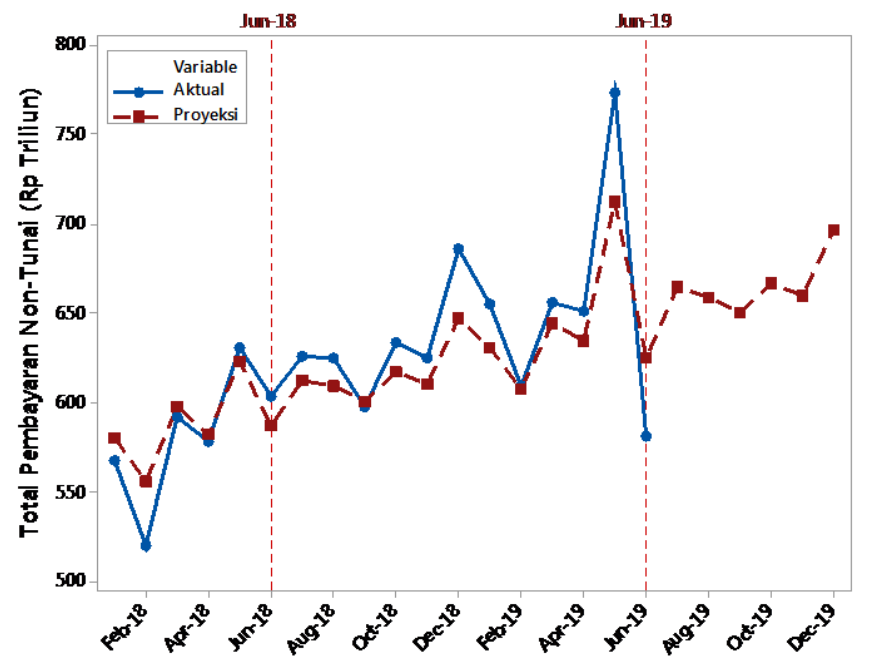

Ket. garis tegak lurus merah adalah bulan terjadinya Idul Fitri

Gambar 5. Plot Deret Waktu Proyeksi Pembayaran Non-Tunai 2018-2019

\section{Kesimpulan}

Konsumsi di Indonesia seringkali meningkat lebih tajam pada periode menjelang hari besar keagamaan, misalnya Idul Fitri. Sementara, bulan jatuhnya Idul Fitri tidak selalu tetap karena sistem penanggalannya berbeda dengan kalender Masehi. Sehingga berdasarkan hasil analisis dan pembahasan, diperoleh kesimpulan:

1. Model yang terbukti signifikan dalam mengidentifikasi efek variasi kalender adalah yang mempertimbangkan periode bulan jatuhnya Idul Fitri, periode bulan dan minggu jatuhnya Idul Fitri, tren deterministik dan pola musiman.

Dari koefisien parameter yang diperoleh sebesar 26,8, hal ini mengindikasikan terdapat peningkatan total pembayaran non-tunai tepat pada bulan jatuhnya Idul Fitri. Sedangkan, di bulan dimana Idul Fitri jatuh pada minggu ke-1 dan ke-2, transaksi pembayaran non-tunai secara signifikan lebih rendah dibandingkan satu bulan sebelum Idul Fitri. Selain itu, tren juga memiliki pengaruh yang signifikan terhadap total pembayaran non-tunai. Dengan demikian, total pembayaran non-tunai terbukti secara statistik meningkat dari tahun ke tahun. Terlepas dari signifikannya seluruh indikator bulanan, bulan Desember (akhir tahun) terbukti sebagai periode bulan dengan nilai pembayaran tertinggi.

2. Tiga alternatif model, yaitu regresi deret waktu, ARIMA dan ARIMAX, dibandingkan akurasi proyeksinya dan diperoleh bahwa ARIMAX mampu memperbaiki dan meningkatkan akurasi proyeksi pembayaran non-tunai dibandingkan regresi deret waktu dan juga ARIMA.

3. Model terbaik untuk proyeksi pembayaran non-tunai adalah $\operatorname{ARIMAX}(2,1,1)$ karena memiliki akurasi yang tertinggi dan memenuhi asumsi statistik yang dipersyaratkan. Selain 


\section{Muhammad Luthfi Setiarno Putera}

itu, ARIMAX $(2,1,1)$ juga mampu mengikuti pola, dinamika dan tren total pembayaran nontunai dengan tepat.

\section{Daftar Pustaka}

[1] Goczek, L. dan Witkowski, B. 2015. Determinants of Card Payments. Applied Economics, vol. 48 , no. 16 , hal. 1530-1543.

[2] Tazkiyyaturrohmah, R. 2018. Eksistensi Uang Elektronik sebagai Alat Transaksi Keuangan Modern. Muslim Heritage, vol. 3, no. 1, hal. 23-44.

[3] Wang, Z. dan Wolman, A.L. 2016. Payment Choice and Currency Use: Insights from Two Billion Retail Transactions. Journal of Monetary Economics, vol. 84, hal. 94-115.

[4] Wulandari, D., Soseco, T., dan Narmaditya, B.S. 2016. Analysis of the Use of Electronic Money in Efforts to Support the Less Cash Society. International Finance and Banking, vol. 3 , no. 1, hal. 1-10.

[5] Ozili, P.K. 2018. Impact of digital finance on financial inclusion and stability. Borsa Istanbul Review, vol. 18, no. 4, hal. 329-340.

[6] Lai, Y. W. dan Windawati, A. 2017. Risk, return, and liquidity during Ramadan: Evidence from Indonesian and Malaysian stock markets. Research in International Business and Finance, vol. 42, hal. 233-241.

[7] Setiawan, Suhartono, Ahmad, I.S., dan Rahmawati, N.I. 2015. Configuring calendar variation based on time series regression method for forecasting of monthly currency inflow and outflow in Central Java. AIP Conference Proceedings, vol. 1691, no. 1, id. 050024.

[8] Anggraeni, W., Vinarti, R.A., dan Kurniawati, Y.D. 2015. Performance Comparisons between ARIMA and ARIMAX Method in Moslem Kids Clothes Demand Forecasting: Case Study. Procedia Computer Science, vol. 72, hal. 630-637.

[9] Lin, H. L., Liu, L.M., Tseng, Y.H., dan Su, Y.W. 2011. Taiwan's International Tourism: A Time Series Analysis with Calendar Effect and Joint Outlier Adjustments. International Journal of Tourism Research, vol. 13, no. 1, hal. 1-16.

[10] Ahmad, I.S., Setiawan, Suhartono, dan Masun, N.H. 2015. Forecasting of Monthly Inflow and Outflow Currency using Time Series Regression and ARIMAX: The Idul Fitri Effect. AIP Conference Proceedings, vol. 1691, no. 1, id. 050002.

[11] Suharsono, A., Suhartono, Masyitha, A., dan Anuravega, A. 2015. Time Series Regression and ARIMAX for Forecasting Currency Flow at Bank Indonesia in Sulawesi Region. AIP Conference Proceedings, vol. 1691, no. 1, id. 050025.

[12] Hutama, A.H., Akbar, S. dan Candra, M.Z.C. 2018. Medium Term Power Load Forecasting for Java and Bali Power System using Artifical Neural Network and SARIMAX. IEEE 5th International Conference on Data and Software Engineering (ICoDSE).

[13] Wei, W.W.S. 2006. Time Series Analysis: Univariate and Multivariate Methods 2nd Edition. California: Addison-Wesley Publishing Company Inc.

[14] Armstrong, J.S. 2007. Significance Tests Harm Progress in Forecasting. International Journal of Forecasting, vol. 23, no. 2 , hal. 321-327. 
Muhammad Luthfi Setiarno Putera

[15] Box, G.E.P., Jenkins, G.M, dan Reinsel, G.C. 2008. Time Series Analysis, Forecasting and Control 4th Edition. New Jersey: John Wiley \& Sons Inc. 